\title{
Rethinking the Malaysian Affordable Housing Design Typology in View of Global Warming Considerations
}

\author{
Abdul Malek Abdul Rahman ${ }^{1}$, Norazmawati Md.Sani @ Abd.Rahim ${ }^{1}$, Karam Al-Obaidi ${ }^{1}$, \\ Mazran Ismail ${ }^{1} \&$ Lim Yoke Mui ${ }^{1}$ \\ ${ }^{1}$ School of Housing, Building and Planning, Universiti Sains Malaysia, Pulau Pinang 11800, Malaysia \\ Correspondence: Abdul Malek Abdul Rahman, School of Housing, Building and Planning, Universiti Sains \\ Malaysia, Pulau Pinang 11800, Malaysia. Tel: 60-194-480-205. E-mail: malik@usm.my
}

Received: April 10, 2013 Accepted: June 10, 2013 Online Published: June 27, 2013

doi:10.5539/jsd.v6n7p134 URL: http://dx.doi.org/10.5539/jsd.v6n7p134

\begin{abstract}
With the advent of the global warming and the resulting climate change, many sectors of a country's socio-economic activities have taken several initiatives to reduce environmental destruction without compromising human physiological and psychological needs. This includes human need for comfortable and affordable homes. Over the years, the design typologies for affordable housing have evolved from a two-bedroom to a compulsory three-bedroom dwelling in order to address the cultural need to separate siblings of different sexes in separate rooms. Build up area from the initial 550 square feet has risen to the now 700 square feet. This article advocates for a more humane design to include the element of environmental comfort to come into play in the design typology for future affordable housing even though some compromises have to be made in terms of price. This paper compares the existing affordable housing design status quo and suggests a new design paradigm in view of the requirements by the Malaysian Green Building Index.
\end{abstract}

Keywords: affordable housing, bioclimatic house, sustainable development, housing typology, green building index

\section{Introduction}

With the growing concern of the global warming and climate change, building professionals are advised to look again at the environmental factor in designing buildings in the tropical climates. Many times the same mistake was repeated only to aggravate the already worsening condition of the climate outside the building. Economic progress has been proceeding at an unprecedented pace that created many heat islands in urban areas. Jungles were cleared to make way for economic progress by providing housing estates, factories, commercial areas and institutions. These changes in urban area have been replacing the natural green surroundings with the hard landscaping, which reduce the cooling effects of evapotranspiration, shade as well as the strategy of cooling winds regarding to buildings' density. These issues have affected directly on reducing the reflectivity of urban area and increasing the absorptivity due to the thermal properties of buildings that add heat to the air by conduction. In addition, the burning of fossil fuels to provide electricity for air-conditioning, fans and to operate mechanical and electrical appliances has assisted to generate more heat. By-products of these activities from the energy provided lead to the release of toxic gases such as carbon monoxide from motor vehicles. The release of carbon dioxide to the atmosphere is reaching at an alarming rate that prevented heat to be reflected back to the outer space and thus cause heat to be trapped within the earth's atmosphere. Therefore, these indicators support to create an artificial warming which reflects in the temperature record. Recent studies show that depending on the weather conditions, the overnight temperature in the center of urban areas can reach up to $10^{\circ} \mathrm{C}$ warmer than rural environment (Climate and water agency, 2002). This is known as the Greenhouse Effect.

According to Gill et al. (2011) evidence proofed that built environment is one of the major contributors of energy needs and carbon emissions (Meeting the Energy Challenge, 2007; Fox, 2009). Residential sector plays a significant role contributing almost $30 \%$ of carbon emissions and energy use (King et al., 2008; Utley \& Shorrock, 2008). IEA, 2009 statistics showed that more than $20 \%$ of the electricity in Malaysia is being used in the residential sector. Figure 1 shows the level of $\mathrm{CO}_{2}$ emission in Malaysia is increasing critically (IEA, 2009) since 1970 which represents as one of the highest emitters of $\mathrm{CO}_{2}$ compared to other countries in Southeast Asia. These data show serious indicators of growing in the demand of the energy in the 21 st century. 


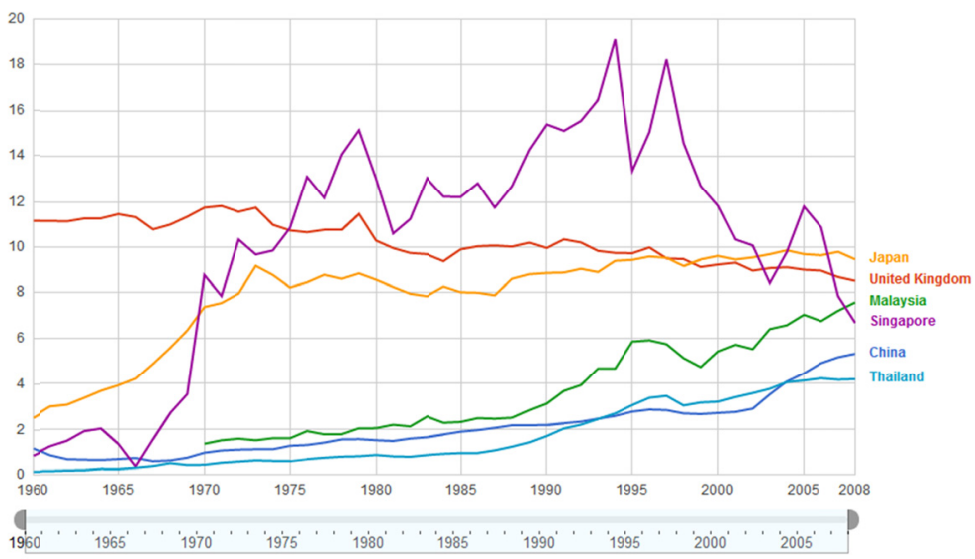

Figure 1. $\mathrm{CO}_{2}$ emissions per capita

Source: World Development Indicators.

According to (Fong et al., 2007a \& 2007b; IGES, 2004) the Urban Heat Island in Malaysia is increased due to human activities that resulted from populations increase in cities. Zainal et al. (2012) indicated that urbanization is one of the major concerns in housing issues, which is directly related to economic development. With the fast-developing economy, the urban population in Malaysia increased rapidly from $25 \%$ in 1960 to $72 \%$ in 2010 . It was estimated that by 2030 more than three quarters of the overall population in Malaysia will settle in urban areas (Jamaliah, 2004). This rate, especially during the last three decades has the demand for affordable housing in many cities (Siwar \& Kasim, 1997).

Currently, developments of Malaysian affordable housing are of low quality due to unawareness and inadequate provisions regarding to built standards, layout arrangement, thermal comfort and quality materials as compared to other forms of domestic buildings (Hanafi, 1999). Regarding to Sulong (1984) and Tan (1980) the earliest research on housing in Malaysia specified qualitatively that the type of housing was not satisfactory to the family housing needs, comfort, social, cultural and religious needs.

Designing for affordability in Malaysia is the greatest challenge of all that the building professionals encounter. Given a contracted space dictated by authorities leaves no creative designs to be appreciated by the users. It is more for the choice of functionality rather than aesthetics. Aesthetics is considered so as to grab the project. After Occupational Certificate has been obtained it is followed by official launching for publicity. Give it another two to three years the positive physical expectations deteriorate. Over the years, many personal items have been accumulated and cluttered the inside of the house cramming the already limited spaces. Telling the users not to hoard personal items would be falling on deaf ears. Furthermore, what has been happening at present is that there are still new buildings sprouting with utter disregard to the energy that it consumes for thermal comfort indoors. Researches have shown that low energy buildings tend to be more desirable to the occupants than conventional building designs, but the building industry is slow to adapt to reverse the building trends. However, available post-occupancy evaluation (POE) research shows real-world building performance aligns poorly with design expectations, and some nominally low-energy buildings perform no better than their more traditional counterparts (Pegg et al., 2007; Bordass et al., 2001). Based on Zaki et al. (2012) conventional terraced house with deep floor plans does not response sufficiently to the local climate. Therefore, this type of house inflicts thermal discomfort, which means high operational energy cost.

\subsection{Affordable Pricing}

Housing affordability relates to a person's ability to pay for their house. It is a complex issue, impacted by the local housing as well as larger economic, environmental and social forces. For example, some households may choose to spend more on housing because they feel they can afford to, while others may not have a choice.

The Malaysian government launched 'My First Home Scheme' to access housing affordability problem the first-time home buyer faces. Unfortunately, this scheme cannot achieve the main objective as the house price is getting higher and higher. According to 'My First Home Scheme', first-time home buyers are individual below 35 years old and obtain a monthly income below than RM3000 (First Home Scheme, 2010). My First Home Scheme assists home buyers to get financial aid in any property, which falls under the price range of RM100 000 to RM220 000. In the recent Malaysia budget, the property price was revised from RM220 000 to RM400 000. 
Basically first home buyer is a young age group that has just started to work for a living. Most of them are graduates Decision to buy a house is made when the household size becomes larger or single person is getting married. HERA (2006) mentioned that a young single person will probably expect to rent but a married couple with a child will consider buying a house.

\subsection{Conventional Present Day Affordable House}

The present-day affordable terrace house requires a transformation in line with changes that has been happening worldwide especially in terms of adapting to the global warming, fast pace modern technological advances, for example the ICT and its peripheries and expanding population (Friedman, 2008). Population growth in Malaysia is predicted to be 33.4 million by 2020 (Ministry of National Unity and Social Development, 1999). Md. Sani (2007) identified six factors that influence affordability of the low-income group to own a house, namely, (i) collective income (ii) household expenditure (iii) type of occupation (iv) level of education (v) breadwinners and (vi) amount of house monthly payment. The breakdown of affordability as given by Md. Sani (2007) is shown in Table 1.

Table 1. Breakdown of income, expenses \& monthly payment

\begin{tabular}{ccccc}
\hline & Income & Expenses & \multicolumn{2}{c}{ Monthly Payments } \\
\hline & $\%$ & $\%$ & $\%$ \\
<RM750 & 19.4 & 24.6 & RM100/RM200 & 68.6 \\
RM750-RM1500 & 59.2 & 59.5 & RM201/RM300 & 16.2 \\
> RM1500 & 18.4 & 12.9 & $>$ RM301 & 12.3 \\
& \multicolumn{3}{c}{$3 \%$ did not respond } \\
\hline
\end{tabular}

From the above table, the majority $68.6 \%$ pay between RM100 to RM200 a month for a house. The proposed design will have to consider this group so that any increase for human comfort would not be a burden in affordability. The low-cost single-storey terraced house typology (Figure 2) is taken as a case study. A maximum of 700 square feet is allowable and therefore, is always constructed to the optimum. A 6.5 meters is a typical frontage width and 11 meters deep. This means that the volume of air mass inside the building will get warmer as the day begins from sunrise to sunset. And to make it worse cement bricks are used as walls and cement roof tiles as roof finishes. The properties of both these materials are that cement based materials readily absorbs and stores heat. At night time when the air is cooler outside the brickwall and roof readily releases the stored heat thus warming the interiors.

A high ceiling interior would take a longer time to warm the air inside, but this is not the case for low-cost design where minimum dimensions rule. Minimum dimensions are acceptable only with the use of building materials that are highly insulated from the sun's heat, but this only raises the building cost. As for the internal activities such as cooking in the kitchen, lights switched on in the middle of the dwelling due to deep plan, TV on, fans to forced circulation of warm air, further contributes to the warm indoor environment. To counter this is to cross ventilate, as the experts say, but when the external air is already warmed up by terrestrial re-radiation due to hard landscaping, equilibrium is reached between the outside and the indoor air temperatures, so no natural cross ventilation is possible. 

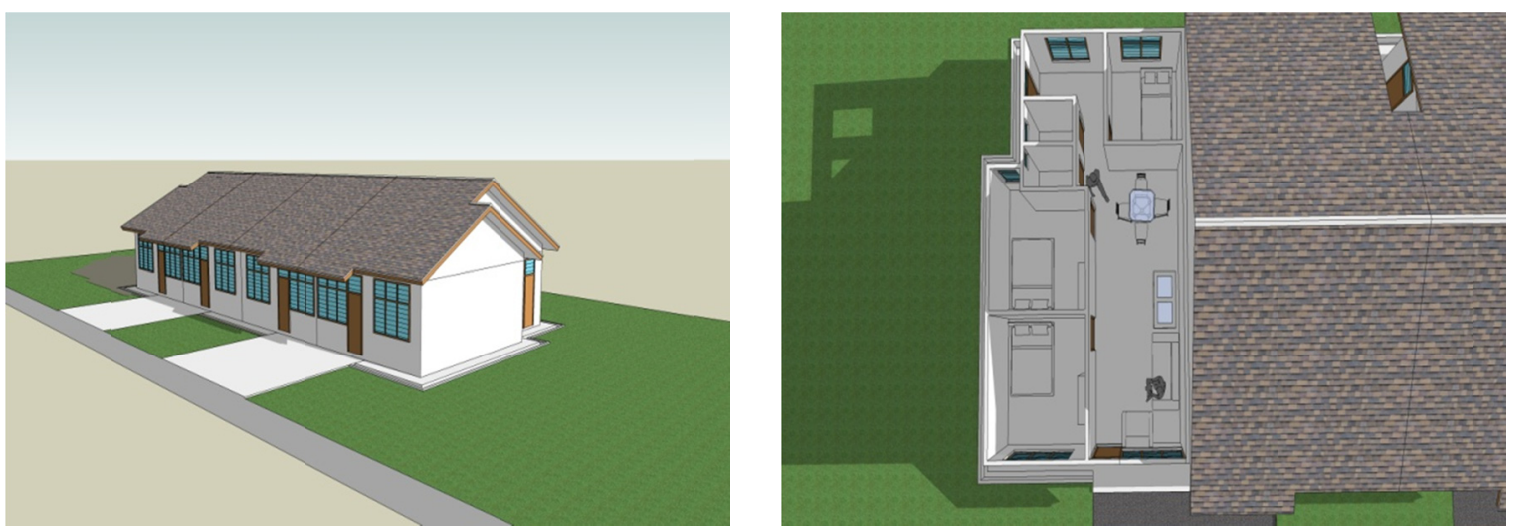

Figure 2. A typical single storey low cost terrace house commonly found in Malaysia

With the long deep plan, internal walls, space cluttered with furniture, inadequate fenestrations obstruct effective cross ventilation for air movement that is badly needed inside for thermal comfort. Even though when there is ample wind that passes through the main frontage of the house via the windows and doors, the air velocity would lose its energy by the time it reaches the middle portion of the interior and fizzled out to calm condition due to the long distance it has to travel from front entrance to exiting at the back. An uncomfortable house would only mean resorting to more money spent for air-conditioning cooling. Generally air-conditioning consumes about one-third the monthly electricity bill. It also releases hot air outside together with carbon content to the atmosphere. House designs not conducive to thermal comfort can have negative effects on the society in general. Many youths would spend most of their nighttime outside because outside is much cooler than inside. The negative effect is that productivity in an office during the daytime can be affected due to the inability to have a proper rest at home. The list can go on. Most people would like to go back to a comfortable home to rest.

Furthermore, people need civilized spaces to live, and planners initiate a development plan that did not consider the ecology of the trees and greenery. Housing layouts are in rank and file irrespectively of orientation, terrain and effective landscaping. The 10\% allocation for green area as required by the Uniform Building By-Law (1984) by most local authorities of all Malaysian states must be relooked at to measure the effectiveness. According to a study by Manum and Adaikalam (2011) on unsatisfied basic needs among low income women in Peninsula Malaysia revealed that a higher percentage of women in the urban were disappointed with the quality of housing compared to their rural counterpart. It is pointless for an Architect to design an ecological building when the rest did not heed to the need for an ecological building. As the name applies, the Green Building Index (GBI) emphasizes on buildings and the immediate surroundings. On a bigger scale, another set of guidelines that emphasize the carbon dioxide reduction has yet to be officially launched is documented as the Low-Carbon Cities Framework (LCCF).

It is possible, and necessary, for the design of affordable housing to confront environmental issues and propose opportunities to decrease carbon emissions and greenhouse gases through a choice of materials, construction technologies and the influence design dictates on how energy is sourced and consumed (SICCM, 2008). Yohanis et al. (2008) found from the measurements in traditional houses that characteristics of the building (for instance floor area, number of occupants, terraced or detached) play a role in determining actual energy needs. According to Atlas (1998) satisfaction with residence space is a function of three variables: user characteristics, physical attributes of the space, and beliefs and perceptions of the user about space. According to Oh (2000), there are three main qualities, which impact the quality of housing that are quality of the house, quality of the close environment and also the quality of the urban site. As a result, physical attributes of the space and quality of the environment is one of the important keys to solve the housing problems.

With this in mind "The environment is where we live, and development is what we all do in attempting to improve our life within that abode, and as a result the two are inseparable. The built and natural environment has a huge impact on the quality of life" (Akintoye, 2006). Comprehensive sustainable development is one of the keys to generate a clean environment. Environmental protection can reduce greenhouse gas (GHG) emissions through the built environment. The most efficient measures to reduce GHG emissions fall into three groups: reducing energy consumption and embodied energy in buildings; utilizing low-carbon fuels for a higher share of renewable energy; or controlling the emissions of non- $\mathrm{CO}_{2}$ greenhouse gases. 
Thus, adapting sustainable development concept design as strategies to terraced houses can improve the indoor thermal comfort and alleviate the need for mechanical cooling. This concept is combining climatology, thermodynamics primarily focusing on heat transfer and human thermal comfort, achieving cooling methods independent of, or infrequently requiring, active systems. To comprehend the environment role more clearly to help in the design, Passive Architecture is a concept designed to be responsive to the local climatic conditions (Zaki et al., 2007). The terminology is conveyed as 'passive' protective approach of house design in shielding occupants from the local climate elements; and 'architecture' place this responsibility to the Architect being the 'Principal Submitting Person' in the Uniform Building By Law and the profession is obligated to create good building design (Zaki et al., 2008). It is also called 'ecological building' and 'green building', which is also well known as 'energy efficient building' and 'healthy building' (Zhu \& Lin, 2004).

In addition, Zhu and Lin (2004) stressed that passive technique requires from the designer to consider (i) Orientation; Thomas and Garnham (2007) recommended building orientation is an essential first action in making "passive" building, and it should be determined by factors of the sun and the prevailing winds; (ii) Building Form; Buildings in the tropics requires to limit its exposure on east and west sides, the optimum form is inevitably rectangular (Konya, 1980); (iii) Wind environment or Ventilation; in the hot and humid climate, ventilation requires larger sizes of window openings to catch a breeze from the prevailing wind (Konya, 1980); (iv) Outdoor thermal environment of the dwelling district; (v) Adequate day-lighting should be provided in all living spaces while caution must be taken in tropics; (vi) Noise pollution and sound insulation; (vii) Wall and Roof Insulation; Konya (1980) stressed especially to adequately insulate the roof because the heat gain in the tropical countries is the maximum on top of a building. Koch-Nielson (2007) proposed that air is the best insulator such as pitched roof with raised ridge that causes stack effect; (ix) Passive Cooling; uses design aspects or technologies to stimulate air flow and cool the environment without dependence on energy sources or power consumption. As a result, in hot and humid tropics such as Malaysia, Passive Architecture design approaches target to avoid heat from the sun, stimulate natural cross ventilation from the prevailing wind and ensure daylight into the building.

Therefore, Malaysia must relook into the present housing design policies and to determine that archaic policies must be obviated, modified and when necessary new ones formulated. Government agencies are still in the dark as to how to go about to improve public housing conditions towards sustainability and time will tell how successful the initiatives would be. A house should be a home and not just a shelter, but existing stock of low-cost houses aims for quantity and compromises on quality. A well designed affordable housing that considers the environment would be conducive to the public health in general and reduce the length of queues at the hospitals. There is now a dire need for an improvement in the living conditions inside the house that would be more conducive to the healthy lifestyle. Wholesome living need not to be expensive but can be affordable if designed for the environment in mind and not just mere production numbers.

\section{Method}

\subsection{Proposed Future Affordable Design}

A rethinking in the design of future affordable houses should consider the effects of global warming. A proposed design shown in Figure 3 is a shift in design paradigm for the affordable housing. The build-up area is almost similar to Figure 2 but slightly bigger with a 10- meter wide frontage and 6.7 meters deep, thereby giving a total of about 67 square meters (722.26 sq.ft.). There are a lot more opening area for good day-lighting and with only a depth of 6.7 meter, effective cross ventilation is predictable. Painting the roof white would help in reflecting the sun's heat. This has been scientifically proven of its effectiveness as a white body. To further cool the roof space, a hybrid turbine ventilator (HTV) is installed to extract hot air from the attic space. The HTV extracts hot air via $40 \mathrm{~W}$ solar-powered extractor fan. As long as there is light the HTV will keep on rotating to extract the hot air out until sunset. Without inducement of extraction, the existing turbine ventilator in the market is not effective enough. Figure 4 illustrates how and where the HTV is used (Ismail \& Abdul Rahman, 2012). There are many inexpensive options when considering applying the passive design elements. These elements prevent heat absorption. Whitewashing reflects heat, HTV extracts hot air out of the building fabric, and orientation prevents the sun from entering into the interiors. 


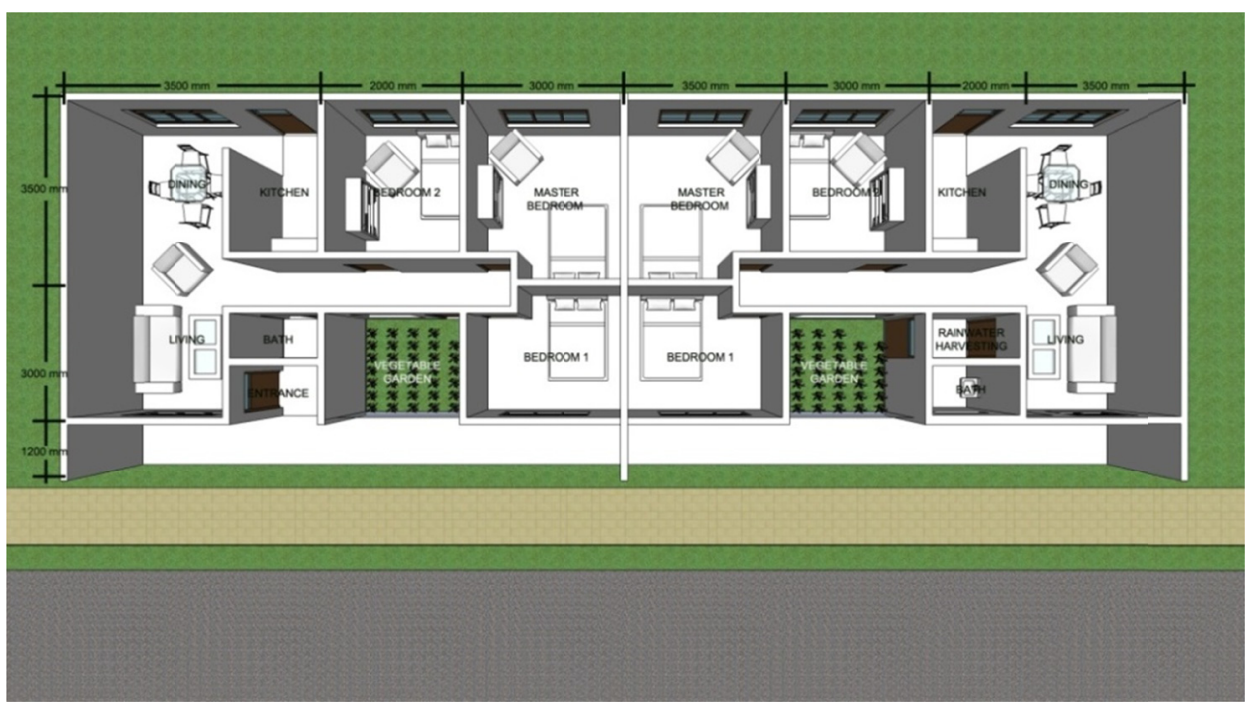

(a)

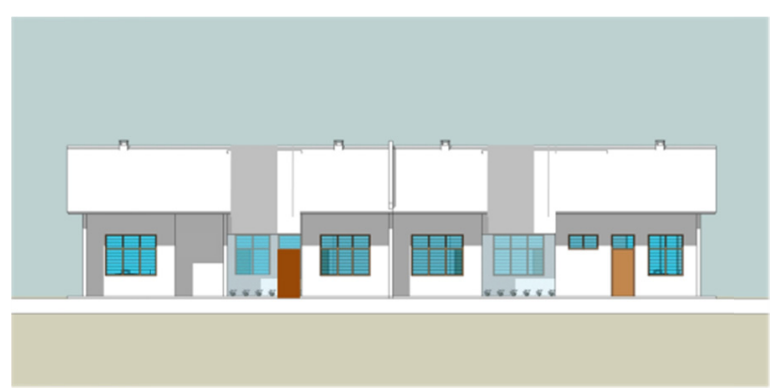

(b)

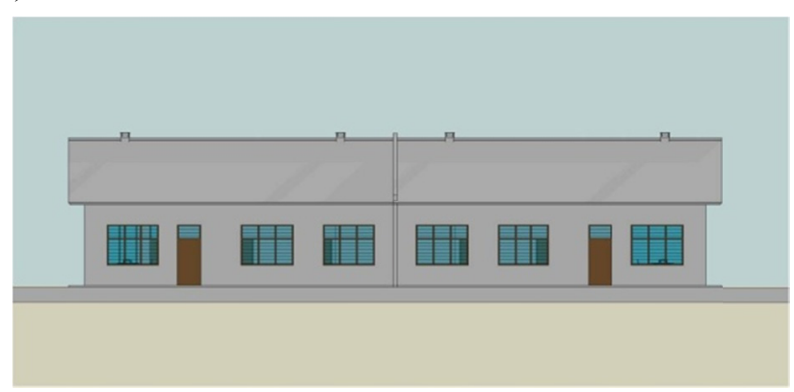

(c)

Figure 3. The future consideration for affordable housing of a 3-bedroom single storey: (a) Plan; (b) Frontage; (c) Back View
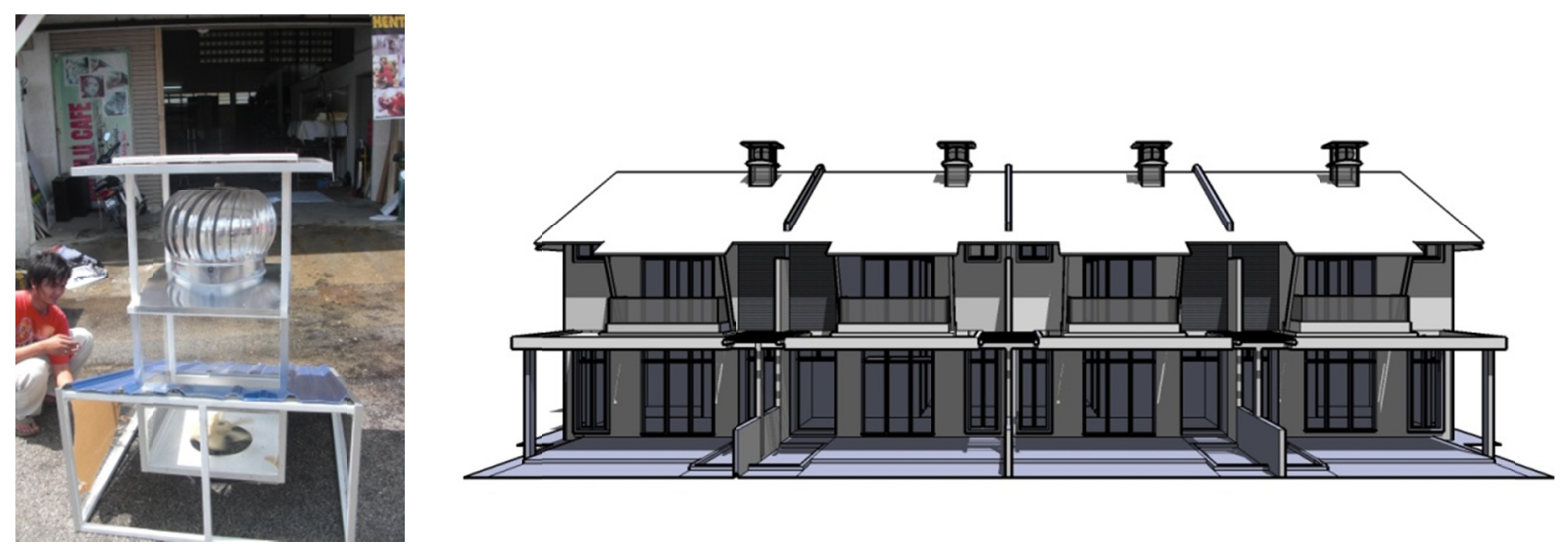

Figure 4. Installation of HTVs for the higher end terrace houses

Source: Ismail, M. and Abdul Rahman, AM, 2012.

Referring to Figure 3 as the proposed layout plan, a small garden comes with the house. From observation, many owners would want to have a small piece of land for vegetable garden. Figure 5 shows an example of a sugar cane garden. This is a good gesture as over time, the nation would be able to reduce the food imports, which at present costs approximately about RM30 billion for the nation. 


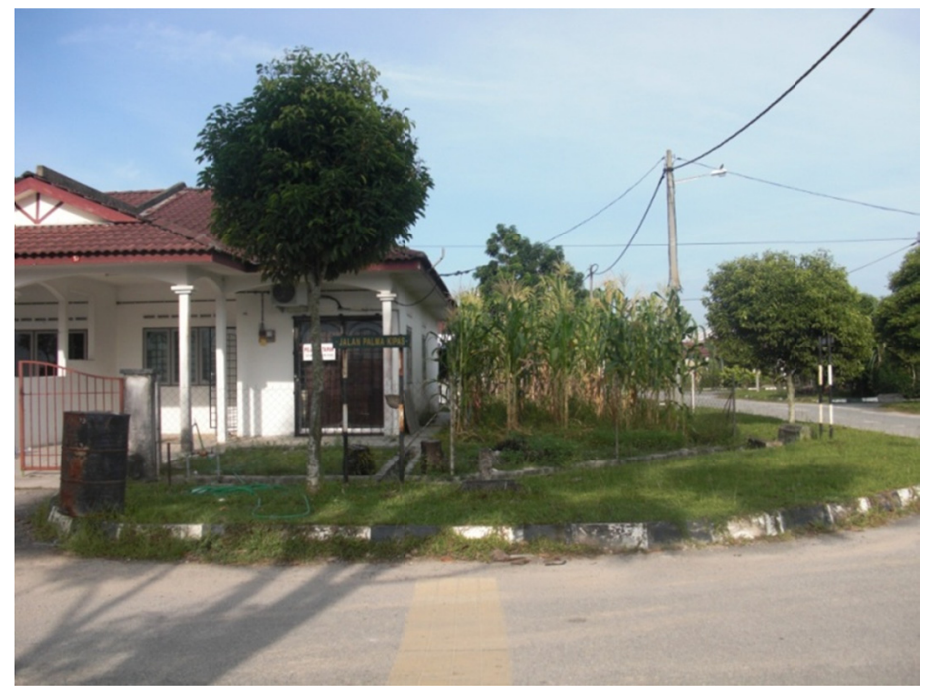

Figure 5. The sugar cane garden

The cost of the house may be raised slightly but in the long run the owner saves on the followings;

a. The narrow plan with longer frontage, whitewashed roof and hybrid turbine ventilator helps to cool the building interior for comfortable living, thereby reduce heavy dependence on active cooling devices. If air conditioning is needed at times it can be set at a temperature higher than usual. Reducing the difference between the outside air and the inside air temperatures mean a lot of energy savings can be achieved.

b. The longer façade faces North-South direction not only allows ample cross ventilation inlet and outlet but also gives generous daylight and thus reduces the dependence of artificial lighting during the daytime.

c. The vegetable garden helps the owner to reduce their food bill by either self-consuming or produce to sell the fruits of labor at the night market. The turf garden also helps to cool the surrounding temperature.

d. By installing a rainwater-harvesting tank would reduce water bill. The rainwater can be used to water the vegetable garden, etc., that do not require treated water.

e. The produce from the garden can either be sold at night market or be consumed thus adding income and less spending.

\subsection{The Environmental Performance of the Proposed Design}

The proposed design has a longer frontage than the conventional design. That means it has a shorter party wall. Longer frontage means accessibility to better cross ventilation and also better daylighting (Saji, 2012). In order to see the differences (Figure 6), comparison can be seen from computer simulation for daylighting. The front and back faces South and North orientation respectively.

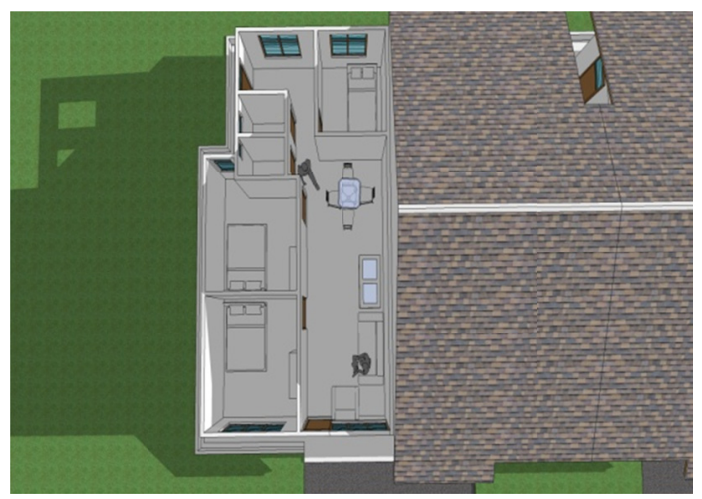

(a)

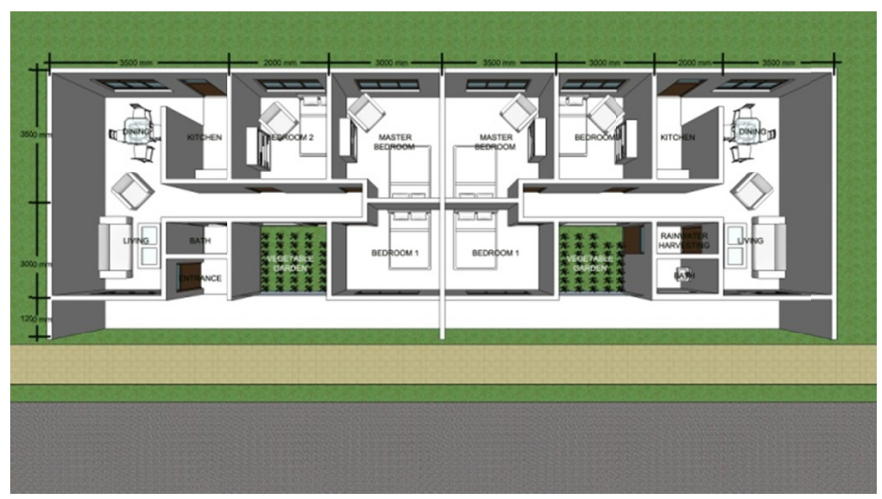

(b)

Figure 6. Affordable terrace houses (a) Conventional design; (b) Proposed design 
Both are built of the same building materials as shown in Table 2 .

Table 2. Building specification for both the conventional and the proposed

\begin{tabular}{|c|c|c|c|c|c|c|c|}
\hline & Materials & Thickness & Conductivity & Density & $\begin{array}{c}\text { Specific } \\
\text { Heat }\end{array}$ & U-Value & R-Value \\
\hline \multirow{3}{*}{$\begin{array}{c}\text { External } \\
\text { brick } \\
\text { wall }\end{array}$} & Stucco & 0.02 & 0.72 & 2659.0 & 837.0 & \multirow{3}{*}{2.67} & \multirow{3}{*}{0.20} \\
\hline & Clay Brick & 0.10 & 0.72 & 1922.0 & 837.0 & & \\
\hline & $\begin{array}{c}\text { Gypsum } \\
\text { Plastering }\end{array}$ & 0.01 & 0.42 & 1200.0 & 837.0 & & \\
\hline \multirow{4}{*}{$\begin{array}{c}\text { Internal } \\
\text { Brick wall }\end{array}$} & Gypsum & 0.01 & 0.42 & 1200.0 & 837.0 & \multirow{4}{*}{2.17} & \multirow{4}{*}{0.19} \\
\hline & Plastering & & & & & & \\
\hline & Clay Brick & 0.10 & 0.72 & 1922.0 & 837.0 & & \\
\hline & $\begin{array}{c}\text { Gypsum } \\
\text { Plastering }\end{array}$ & 0.01 & 0.42 & 1200.0 & 837.0 & & \\
\hline Roof & Clay tiles & 0.02 & 0.84 & 1900.0 & 800 & 6.10 & 0.02 \\
\hline Ceiling & $\begin{array}{c}\text { Gypsum } \\
\text { Plasterboard }\end{array}$ & 0.00 & 0.16 & 950.0 & 840 & 3.90 & 0.05 \\
\hline \multirow{3}{*}{ Floor } & Sand & 1.00 & 0.35 & 2080.0 & 840 & \multirow{3}{*}{0.31} & \multirow{3}{*}{0.22} \\
\hline & Cast concrete & 0.15 & 1.40 & 2100.0 & 840.0 & & \\
\hline & Screed & 0.05 & 0.41 & 1200.0 & 840.0 & & \\
\hline
\end{tabular}

\section{Results and Discussion}

\subsection{Daylighting Simulation}

The simulated daylighting diagram in Figure 7 is an obvious observation that the proposed typology has the desired daylight for the living room saving energy by not switching any artificial lights during daytime otherwise during wake hours artificial lighting becomes necessary.
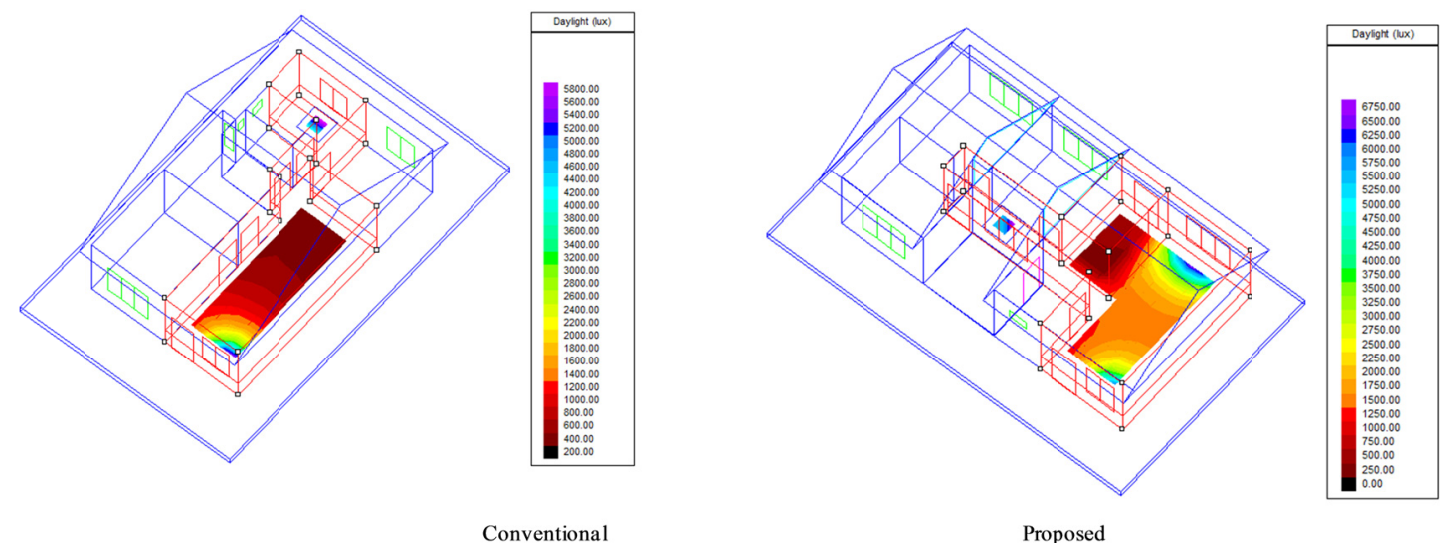

Figure 7. Daylight simulations for both the conventional and proposed

The conventional layout has another additional setback in that the middle room is in perpetual darkness (Figure 8) and therefore, during daytime and night artificial lighting is required except for sleeping hours that can vary from 12:00 midnight to 6:00 am. Lights off for only six hours everyday is considered inefficient and not to be recommended. 


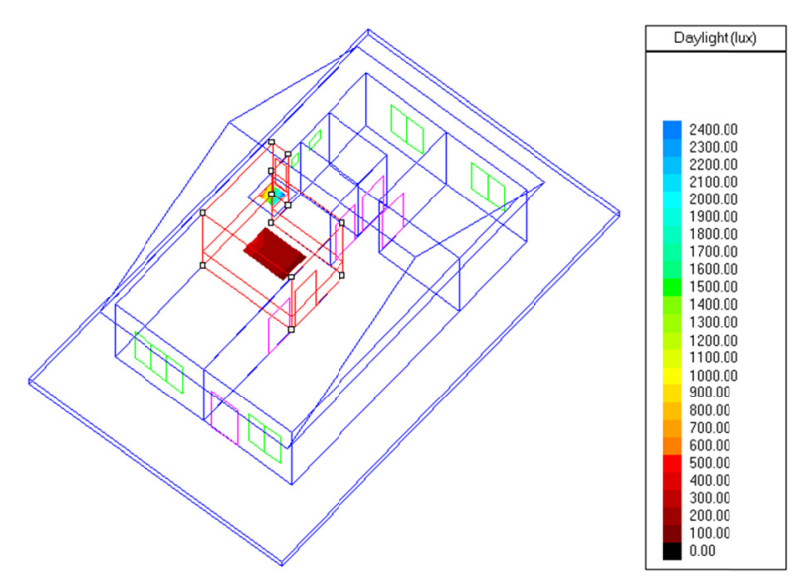

Figure 8 . The middle room of the conventional layout is perpetually dark

\subsection{Temperature Simulation}

As for the general indoor air temperature between these two layouts, the comfortable sleeping hours are found in the proposed typology because at night, most of the temperature in at least $1{ }^{\circ} \mathrm{C}$ lower than the conventional. The conventional fare better during the daytime starting from $11.30 \mathrm{am}$ to $5.30 \mathrm{pm}$ but only for an average difference of $0.34^{\circ} \mathrm{C}$. This is without any air movement for both and is considered negligible to the proposed layout. Any air movement created by the ceiling fan would dissipate the heat readily. To account for this behavior why the proposed layout indoor temperature is higher than the conventional is because of the short distance from front to back thus exposing to warm air easily entering the interior.

During the daylight hours, most occupants would be away working and best when returning to a house that gets cool easily to provide a comfortable resting period from the night to the early morning hours (Figure 9).

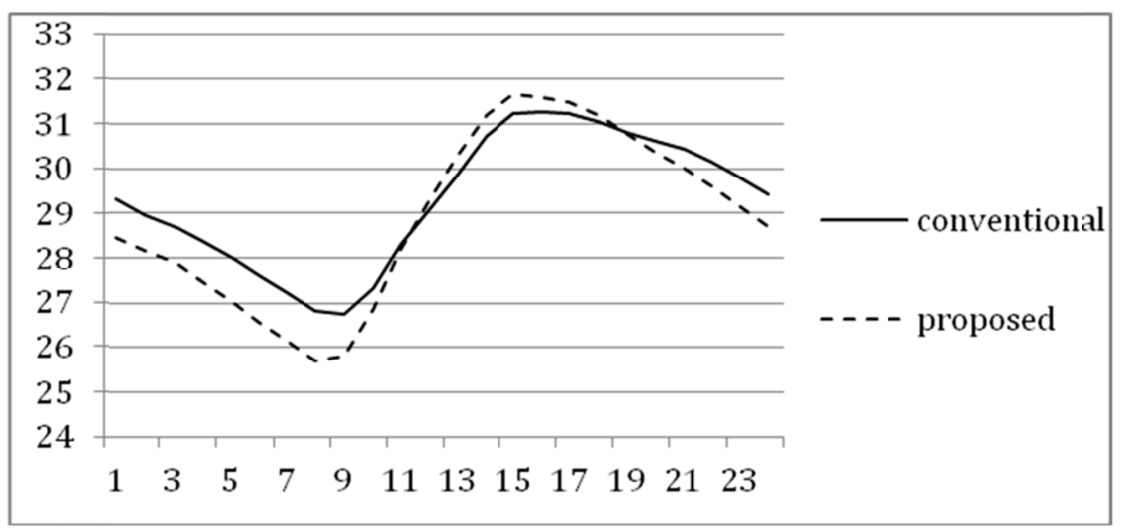

Figure 9. Temperature difference between conventional and proposed layouts

In order to convince the authority that the proposed design is viable economically, this paper will compare the cost of a conventional low cost terrace house with the cost of the proposed new design. The cost calculation is only an estimated based on the minimum specification in line with low-cost housing in Malaysia. Table 3 below shows the comparison, including the additional costs of the proposed design for one intermediate unit. 
Table 3. Cost Comparison between Conventional and Proposed layout plans for one intermediate unit

\begin{tabular}{ccc}
\hline Item & Conventional Low Cost Terrace (770sq ft) & Proposed Design (722sq ft) \\
\hline Building Cost & $\mathrm{RM} 34650.00 @ \mathrm{RM} 45 / \mathrm{sqft}$ & $\mathrm{RM} 32490.00 @ \mathrm{RM} 45 / \mathrm{sqft}$ \\
1. Additional windows & - & $\mathrm{RM} 2900.00$ \\
2. Rainwater harvesting & - & $\mathrm{RM} 2000.00$ \\
Total Cost & & $\mathrm{RM} 37390.00$ \\
\hline Cost per sq ft. & & $\mathrm{RM} 52.00$ \\
\hline
\end{tabular}

Due to the difference in floor area between the conventional low cost terrace and the new design, the total cost of one intermediate unit does not compare apple to apple. Therefore, the cost per sq $\mathrm{ft}$. will provide a clearer picture of the cost between both designs. Table 3 shows that the cost of proposed design is $0.08 \%$ cost higher than the conventional design even though the floor area is comparatively less. This additional cost is due to the extra number of windows and rainwater harvesting installation. However, these additional costs are to be absorbed by the savings from the reduced use of artificial lighting, improved ventilation, water savings from rainwater harvesting and sale of vegetable produce from the small garden that comes together with the design. Overall, there is an addition of RM7.00 per sq. $\mathrm{ft}$. for the proposed design. Nevertheless, this $0.08 \%$ increase in cost will create better living conditions that may improve the general health for the occupants. The newly introduced passive design elements, the vegetable gardens and the rainwater harvesting will eventually offset the increase in building cost;

(i) Firstly, the reduced indoor air temperature means decreased electricity consumption to cool for thermal comfort.

(ii) Secondly, more windows mean more daylight enters the interior and therefore, less electricity consumption for artificial lighting.

(iii) Thirdly, the vegetable gardens provide the occupant the opportunity to grow their own vegetables for personal consumption or can be grown to be sold at night markets. These gardens add to household income by not buying vegetables or fruits at markets or selling them whereas, add to their household income.

(iv) Fourthly, the rainwater harvesting reduces water consumption for the vegetable garden, for washing compounds or vehicles. Thus, water savings mean savings in water bill.

\section{Conclusion}

This paper provides a clear view of the relationship between global warming effects and the affordable housing design and how these issues affect affordability. The results lead to adapted various concepts and strategies to fit the requirements for existing condition. These modifications and alterations help to curb the extensive needs of energy by providing more appropriate built environment for human comfort. This step leads to zoom clearly on the relation between economic and environmental situation in building environment by solving the problem of unprofessional design methods in the construction field. As a result, these findings could help to control the expansion of greenhouse gases in the future while maintaining for optimum and affordable price. Therefore, from observations and literature reviews on affordable housing in the Malaysian market, a few recommendations may aid architects and designers in the coming up with creative typologies while achieving energy efficiency and indoor comfort. Through empirical and simulation studies, it has shown that not only in providing the occupiers the thermal comfort but also psychological comfort as well. The conventional design seemed to be claustrophobic, and this has to be addressed by the proper orientation as shown in Figure 3. Thus, comfort has to be two pronged, thermal and psychological. Indoor wall should be given a lively finish and stimulating visually to enhance the psychological aspect of the human behavior. Pastel light color for internal walls would be the cheapest and also stimulating. Providing a courtyard would give multi-purpose spaces that allow the occupiers the choice of deciding what greens they prefer. And if done consistently that particular row of houses would give a pleasant setting by the variety of plants planted at intervals between the units. It would add color and life to the neighborhood. Occupiers or owners must also be educated on the use of energy in homes and how to minimize energy usage without compromising on living standards. They are also to make some habitual adjustments to accommodate the physics of microclimatic behavior. Understanding the microclimate would be a great advantage because the owner would be able to do inexpensive adjustments to suit their lifestyles and finally there 
must be some sort of regulations incorporated in the Sales \& Purchase Agreement to prevent any renovations that may disrupt the microclimate that may also affect their neighbors' comfort.

\section{Acknowledgements}

The authors would like to thank Universiti Sains Malaysia (USM) for the financial support provided for this research project.

\section{References}

Akintoye, A. (2006). A Public Partnership for Sustainable Development of Infrastructure in Developing Countries Covenant University, Nigeria Pg. 433.

Al-Mamum, A., \& Adaikalam, J. (2011). Examining the level of unsatisfied basic needs among low-income women in Peninsular Malaysia. International Research Journal of Finance and Economics, 74, 89-96.

Atlas, N. E. a. O., A. (1998). Spatial adaptability and flexibility as parameters of user satisfaction for quality housing. Building and Environment, 33(5), 315-323. http://dx.doi.org/10.1016/S0360-1323(97)00050-4

Australia's national weather, climate and water agency. (2002). The green house effect and climate change. Retrieved June 5, 2013, from http://www.bom.gov.au/info/GreenhouseEffectAndClimateChange.pdf

Bordass, W., Cohen, R., Standeven, M., \& Leaman, A. (2001). Assessing building performance in use, 2. Energy performance of the probe buildings. Building Research and Information, 29(2), 114-128. http://dx.doi.org/10.1080/09613210010008036

Duffy, D., \& Quail, A. (2005). First Time Buyers in The Irish Housing Market: A Survey Of Permanent tsb First Time Buyers. The Economic and Social Research Institute. Dublin.

First home scheme. (2010). IN Skim Rumah Pertamaku (SRP). Retrieved June 3, 2013, from http://www.srp.com.my

Fong, W. K., Matsumoto, H., Lun, Y. F., \& Kimura, R. (2007a). System Dynamic Model for the Prediction of Urban Energy Consumption Trends. Proceeding I of the 6th International Conference on Indoor Air Quality, Ventilation \& Energy Conservation in Buildings (IAQVEC 2007), 28-31 October 2007, Sendai, Sendai, Japan. 762-769.

Fong, W. K., Matsumoto, H., Lun, Y. F., \& Kimura, R. (2007b). System Dynamic Model as Decision Making Tool in Urban Planning from the Perspective of Urban Energy Consumption. Seminar Proceedings of the 3rd Seminar of JSPS-VCC (Group VII), 10-11 September 2007, Johor Bahru, Malaysia. 99-110.

Fox, T. (2009). Climate Change: Have We Lost the Battle, Institute of Mechanical Engineers.

Friedman, T. L. (2008). Hot, Flat and Crowded, Allen Lane Penguin Books, London, UK.

Gill, Z. M., Tierney, M. J., Pegg, I. M., \& Allan, N. (2011). Measured energy and water performance of an aspiring low energy/carbon affordable housing site in the UK. Energy and Buildings, 43(1), 117-125. http://dx.doi.org/10.1016/j.enbuild.2010.08.025

Hanafi, Z. (1999). Rekabentuk Bangunan Dalam Iklim Panas dan Lembap di Malaysia, Dewan Bahasa dan Pustaka, Kuala Lumpur.

HERA (Housing Education and Research Association). (2006). Introduction to Housing. Pearson Education Inc. New Jersey.

Hulchanski, J. D. (1995). The concept of housing affordability: six contemporary uses of the housing expenditure-to-income ratio. Housing Studies, $10(4), \quad$ 471-491. http://dx.doi.org/10.1080/02673039508720833

IGES. (2004). Urban Energy Use and Greenhouse Gas Emission in Asian Mega Cities: Policies for a Sustainable Future. Kanagawa: Institute of Global Environmental Strategies.

International energy agency (IEA). (2009a). Electricity generation by fuel in 2009. Retrieved June 5, 2013, from http://www.iea.org/stats/pdf_graphs/MYELEC.pdf

International energy agency (IEA). (2009b). Electricity/Heat in Malaysia in 2009. Retrieved June 5, 2013, from $\mathrm{http}: / / w w w . i e a . o r g /$ stats/electricitydata.asp?COUNTRY_CODE=MY

Ismail, M., \& Abdul Rahman, A. M. (2012). Possibilities of enhancing building ventilation and aesthetic appearance by implementing solar-wind driven turbine ventilator, Proceedings of the 3rd International 
Conference on Environmental Research and Technology (ICERT2012), 30 May - 1 June 2012, Penang, Malaysia, pp. 30-35.

Jamaliah, J. (2004). Emerging trends of urbanisation in Malaysia. Journal of the Department of Statistics, Malaysia, 1, 43-54.

King, K., Goodwin, J., Passant, N., Brophy, N., \& Tsagatakis, I. (2008). Local and Regional $\mathrm{CO}_{2}$ Emissions Estimates for 2005-2006 for the UK, AEA report to DEFRA.

Koch-Nielsen, H. (2007). Stay cool: A design guide for the built environment in hot climates. London: The Cromwell Press.

Konya, A. (1980). Design primer for hot climates. London: The Architectural Press.

Legal Research Board. (2003). Uniform Building By-Laws 1984 [G.N.5178/85. (Clause 39 (1) to (4), 40 (1) and (2)), International Law Book Services, Kuala Lumpur, Malaysia.

Md Sani, N. (2007). Kemampuan pemilikan rumah kos rendah di Kuala Lumpur, A PhD Thesis submitted to the Universiti Sains Malaysia, Penang, Malaysia. (Translation: Affordability of a low-cost house in Kuala Lumpur).

Meeting the Energy Challenge. (2007). A White Paper on Energy, DTi, The Stationery Office, UK.

Ministry of National Unity and Social Development. (1999). Kuala Lumpur, Malaysia.

Oh, L. S. (2000). Housing satisfaction of middle income households in Bandar Baru Bangi, Selangor. Dissertation, Universiti Pertanian Malaysia.

Pegg, I., Cripps, A., \& Kolokotroni, M. (2007). Post-occupancy evaluation performance of five low-energy schools in the UK. ASHRAE Transactions, 113(2).

Saji, N. (2012). A Review of Malaysian Terraced House design and the Tendency of Changing. Journal of Sustainable Development, 5(5), 140-149. http://dx.doi.org/10.5539/jsd.v5n5p140

Shelter initiative for climate change mitigation (SICCM). (2008). Low-cost sustainable housing, materials + building technology in developing countries. Retrieved June 5, 2013, from http://www.habiter-autrement.org/im-daara/contributions-daara/Low-Cost-Sustainable-Housing,-BuildingMaterials.pdf

Siwar, C., \& Kassim, M. Y. (1997). Urban development and urban poverty in Malaysia. International Journal of Social Economics, 24(12), 1524-1535. http://dx.doi.org/10.1108/03068299710193958

Sulong, M. (1984). Perumahan Awam Kos Rendah di Terengganu: Isu, Masalah dan Penerimaan Masyarakat. Malaysia: Universiti Kebangsaan Malaysia.

Tan, S. H. (1980). Factors influencing the location, layout and scale of low-cost housing in Malaysia.

Thomas, R., \& Garnham, T. (2007). The environments of architecture: Environmental design in context. Great Britain: Taylor \& Francis.

Utley, J. L., \& Shorrock, L. D. (2008). Domestic Energy Fact file 2008, BRE, EST and DECC.

World Development Indicators. (2009). $\mathrm{CO}_{2}$ emissions per capita. Retrieved June 5, 2013, from http://www.google.com/publicdata/explore?ds=d5bncppjof8f9_\#!ctype $=1 \&$ strail=false \&bcs $=\mathrm{d} \& n s e l m=h \&$ met_y=en_atm_co2e_pc\&scale_y=lin\&ind_y=false\&rdim=region\&idim=country:MYS:JPN:SGP:THA\&if $\mathrm{dim}=$ region\&tdim $=$ true\&hl=en_US\&dl=en_US\&ind $=$ false

Yohanis, Y. G., Mondol, J. D., Wright, A., \& Norton, B. (2008). Real-life energy use in the UK: how occupancy and dwelling characteristics affect domestic electricity use. Energy and Buildings, 40, 1053-1059. http://dx.doi.org/10.1016/j.enbuild.2007.09.001

Zainal, N. R., Kaur, G., Ahmad, N. A., \& Khalili, J. M. (2012). Housing Conditions and Quality of Life of the Urban Poor in Malaysia. Procedia - Social and Behavioral Sciences, 50(0), 827-838.

Zaki, W. R. M., Nawawi, A. H. \& Sh. Ahmad, S. (2007). Case study in passive architecture: energy savings benefit in a detached house in Malaysia, Proceedings in the 24th Conference on Passive and Low Energy Architecture, University of Singapore, 259-266.

Zaki, W. R. M., Nawawi, A. H., \& Sh. Ahmad, S. (2008). Energy savings benefit from passive architecture. Journal of Canada Centre of Science Education, 3, 51-63.

Zaki, W. R. M., Nawawi, A. H., \& Sh. Ahmad, S. (2012). Environmental Prospective of Passive Architecture 
Design Strategies in Terrace Houses. Procedia - Social and Behavioral Sciences, 42(0), 300-310.

Zhu, Y., \& B. Lin. (2004). Sustainable housing and urban construction in China. Energy and Buildings, 36(12), 1287-1297. http://dx.doi.org/10.1016/j.enbuild.2003.11.007

\section{Copyrights}

Copyright for this article is retained by the author(s), with first publication rights granted to the journal.

This is an open-access article distributed under the terms and conditions of the Creative Commons Attribution license (http://creativecommons.org/licenses/by/3.0/). 